\title{
HESSEN ANAYASASI
}

\section{Ceviren : Nermin ABADAN}

29 Ekim 1946 tarihli Büylik Hessen constituant meclisinin umumi oturumunda uçüncủ defa olarak okunduktan sonra kabul edilmiştir.

1 Aralı 1946 tarihinde yapllan oy vermede Büytuk Hessen seçmenlerine teklif edilen anayasanin metni.

Hessen'in 30 Haziran 1946 tarihinde seçilen constituant meclisi 15 Temmuzda anayasa kurma faaliyetine başladı. Anayasa hazirlama komisyonunun materyeline istinaden altı umumî heyet oturumunda bir anayasa metni hazırlandı ve bu metin 26 Ekimđe yapılan kapanıs töreninde 6 ya karģ 82 oyla kabul edildi. Askerí hükûmet bu teklife kar\$̧ı bir itirazda bulunmamıştır. Büyük Hessen nüfusu 1 Aralık tarihinde yaplacak oy vermede bu tasarıyı anayasa olarak kabul edeceğini yoksa o gün seçilecek bir constituant meclisin yeni bir metin hazırlıyacağı hususunda karar verecektir.

Tercumeye esas tutulan anayasa metni München -- Schellingstrasse 39 mukim "Die Neue Zeitung" tarafından basılmıstır.

\section{BIRINCI KISIM}

\section{N S A N H A K L A R I}

$I$ - Eşitlik ve hürriyet :

Madde 1 - Büttin insanlar cins, menşe, dinî ve siyasî kanaat farkı oımaksızın Kanun önünde eşittir.

Madde 2 - Insan hürdür. Başkalarının haklarına halel getirmemek veya içtimai varlığn anayasaya uygun nizamın bozmamak şartile istediğini yapma veya yapmamada serbesttir.

Kimse bir kanun veya bir kanuna dayanan nizamnamenin istilzam ettig, veya milsaade etmedikçe bir şey yapmağa, yapmamağa veya bir hale tahammül etmeğe zorlanamaz.

Kanun kudreti tarafindan hakkı ihlâl edilen kimse için hukuk yolu açıktır.

Madde 3 - Insanin hayat ve sihhatine, seref ve haysiyetine dokunulamaz.

Madde 4 - Cemiyet hayatının temeli saylan evlilik ve aile kanununun bzel himayesi altındadır.

Madde 5 - Kişinin hürriyetine dokunulamaz.

Madde 6 - Herkes istediø̆i yerde kalmak ve yerleşmekte serbesttir.

Madde 7 - Hiçbir Alman yabanci bir devlete teslim edilemez. Bu anayasada tesbit edilen anahaklamna halel gelmis ve dis memleketlerinde takip edilirken Hessen'e siğnmis olan yabanclar sinur dis ye iade edllmekten korunurlar. 
Madde 8 - Meskene dokunulamaz.

Madde 9 - tnanc, vicdan ve kanaat hürdür.

Madde 10 - Hiç kimsenin ilim veya sanat alanindaka yaratmasina ve eserlerini yaymasina engel olunamaz.

Madde 11 - Herkes kanaatini serbestçe ve alenen izhar etmekte hürdür. Bu hal bir hizmet mủnasebeti dolayısiyle de tahdit edilemez ve kimse bu hakkı kullandığından dolayı bir mahrumiyete ugrratılamaz. Ancak kararlaştımlan faaliyet muayyen bir siyasî, dini istikamet veya dünya görünüşe hizmet hedefini gthdưyorsa ve iştirak edenlerden biri bundan imtina ederse, hizmet milnasebeti bozulabilir. Basun sansürì caiz değildir.

Madde 12 - Posta sirm masundur.

Madde 13 - Herkes buitün ilim ve tecrube alanlarinda ve baskalarnn kanaatlari hakkunda basılmıs eserler, radyo yayınları ve diğer suretlerle bilgi edinme halkkına sahiptir.

Madde 14 - Bütün Almanlar haber vermeden ve özel bir izin almaksızin silahsly ve emniyeti bozmiyacak sekilde toplanmak hakkuna sahiptirler.

Açık havada yaplacak toplantılar için kanunla önceden izin alma mükellefiyeti konulabilir.

Madde 15 - Bütin Almanlar dernek ve birlikler kurmak hakkuna sahiptirler.

Madde 16 - Herkes tek veya toplu bir sekilde ilgili makam veya millet meclisine şikâyet veya dileklerini bildirme hakkuna sahiptir.

\section{INSAN HAKLAARIN SINIRLARI VE TEMINATI}

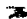

Madde 17 - Hic kimse anayasaya aykun veya onu tehlikeye düşüren bir hareketi söz, toplanma ve dernek kurma hürriyetleri ile ilm̊ veya güzel sanatlara ait eserleri yayma haklarma istinat edemezler.

Madde 19 - Hâkim cezayı müstelzim bir halin vukuundan şiddetle sulphelendiğ zaman tevkif, ev arasturma ve posta surrina muidahaleye karar verebilir. Failin takibi hemen harekete geçmeği gerektirdigi hallerde ev araşturma izni sonradan verilebilir.

Yakalanan herkes 24 saat içinde kendisini sorguya çekecek, serbest brrakulmasuna veya tevkifine karar verecek ve tevkif halinde nihaî kazai karara kadar her ay yeniden tevkifinin gerekip gerekmedigini tetkik edecek olan hâkimin huzuruna çkarilır. Tevkifin sebebi yakalanan kimseye hemen ve arzusu tizerine hâkimin kararın takip eden yirmidört saat içinde yakınlarına bildirilir.

Madde 20 - Kimse kanunî merciinden baska bir mahkemeye sevk edilemez. Olağanüstui ve özel ceza mahkemelerine cevaz yoktur.

Yetkili bir mahkeme kendisini kesinleşmiş bir kararla suçlu ilân etmedikçe, herkes masum saylur. Adli mïzaharet yolu ile müdafaa hakkı tahdit edilemez.

Madde 21 - Cezayı müstelzim bir halden dolayı suçlu olduğuna karar verilen bir kimse ceza kanunlar gereğince kazai bir hükümle hürriyetinden ve medeni larından kısmen veya tamamen mahrum edilir. Suçun çok ağır olması halinde ölüm cezasi da verilebilir.

Ceza fiilin ağırı̆̆ına göre biçilir.

Bütün mahbuslara insani gekilde muamele edilmelidir.

Aadde 22 - His bir capa kanunu makabline gamil değildir. Meğer id flilin iglendiği tarihte yürthrlukte olan kanuna göre fail için daha elverişli sartlar olsun. 
Hiç kimse kendisinin yapmadiğı fiil veya ihmallerden dolayı ceza hukuku bakımindan sorumlu tutulamaz veya bunlardan dolayı ceza görmez.

Kimse ayni fiilden dolayı bir defadan fazla cezalandirulmaz.

Madde 23 - Durumu ile hemcinsleri için esaslı bir tehlike teşkil eden akıl veya beden hastası bir mliesseseye gönderilir.

Hasta bu tedbirlerden dolayı hâkime bașurma hakkına sahiptir. Teferruat kanun tarafindan tayin edilir.

Madde 24 - Şahsî hürriyetin başka tủrlü tahdidi ancak kanun çerçevesinde ve çărilanların mahkeme huzuruna celbi, sahitlerin vazifelerini ifası, mahkeme inzibatının temini, mahkeme hükümlerinin infazı ve kanuna uygun idarî nizamları tatbiki için gerektiği nisbette caizdir.

Madde 25 - Herkes kanunun tayin ettiği ölçüde onursal görevler deruhte etmek ve devlet ile belediye için şahsi hizmetlerde bulunmakla mükelleftir. Bir hizmet münasebeti ile bağlı bulunması halinde kendisine gereken bos zaman tahsis edilmelidir.

Teferruat kanunla tayin edilir.

Madde 26 - Bu anahaklar değiştirilemez. Bunlar kanun vazı1y, hâkim ve idareyi doğrudan doğruya bağlar.

\section{SOSYAL VE EKONOMLK HAK VE ODEVLER}

Madde 27 - Sosyal ve ekonomik nizam insan şahsiyet ve şerefinin tanınması esasina dayanir.

Madde 28 - Insanın çalı̧ma gücü devletin özel himâyesi altındadır. Herkes kabiliyetine göre bir iş hakkına sahiptir. ve sahsi hüriyetine halel gelmemek gुartiyle çalıması ahlâki bir mükellefiyettir.

Kendi kusuru olmaksızın işsiz kalanın şahsi ve geçinđirmekle mükellef olduğu yakunları için geçim imkânını sağlanması istemeğe hakkı vardır.

tşsizlik sigortası kanunla tayin edilir.

Madde 29 - Bütün müstahdem, iş̧̧i ve memurlar için mlittehit bir iş hukuku yapılmalıdir. Bu iş hukukunun çerçevesi dahilinde toptan anlasmalar ancak sendika ile muesseseler veya onların temsilcileri tarafindan aktedilebilir. Bunlar yalnız isçlerin lehine şartlar tesis eden bağlayıcı hukuk yaratır.

Tahkim usulü kanunen tesbit edilir.

Grev hakkı ancak sendikalar grev ilan ettikleri takdirde tanınir.

Lokout kanuna aykiridir.

Madde 30 - Iş şartlan ile alanın shhhatini, haysiyetini, aile hayatın ve kiltỉrel intiyaçlamn teminat altına alacak sekilde tanzim edilmelidir. Bilhassa genclerin bedenî, fikrî ve ahlâkî gelişimi bu şartlarla tehlikeye dủşürủlmemelidir.

Kanun anne ve çocukların himayesi için tedbirler alır ve kadına yaratıcı vatandaß̧ sıfatiyle yaptığ ödevlerini kadın ve annelik mükellefiyetleriyle telif imkânın sağlar.

Çocukların çalıştımıması yasaktır.

Madde 31 - Kanunî çalışma mưdeti sekiz saatlik iş gunuludur. Pazar ve kanunl bayram günlerinde çalışlmaz. Istisnalar umuma hizmet ettigi takdirde kanun veya sendika anlaşmaları yoliyle caizdir. 
Madde 32 - 1 Mayıs çalısan bütün insanların kanuni bayram günüdür. Bu gün sosyal adaleti, ilerleme, barış, hürriyet ve milletlerarası antlaşmaya taraftarliğının semboludür.

Madde 33 - tș ticreti yapılan işi karşılamak ve çalı̧anla geçindirmek zorunda olduğu kimselerin geçinmesine yetmelidir.

Kadın ve gençler ayni faaliyet ve ayni semere için ayni licreti almağa haik sahibidir. Is zamanına tesadüf eden bayram günlerin iş thcreti de verilir.

Madde 34 - tşalan herkes senede hiç olmazsa oniki günlük bir uicretli tatile istihkak kespeder. Tefarruat kanunla tayin edilir.

Madde 35 - Bütün halka șâmil bir sosyal sigorta hazırlanmalıdır. Bu sigorta. maksada uygun şekilde yapilmalıdır. Sigorta edilenlerin muhtar idaresi tanınir. Organları umumî, eşit, hür ve gizli şekilde seçilir. Teferrüat kanunla tayin edilir.

Sosyal sigortanun ödevi milletin sagllk durumunu koruyucu tedbirlerle korumak ve yukseltmek, hasta, gebe ve lohusalara gereken yardımı göstermek ve dar gelirli, malallar ve geride kalanlara yeter derecede bir geçim saglamak ve onlarun ihtiyarlığnı teminat altına almaktır.

Sagllk işlerin tanzimi devlete aittir. Teferruatı kanun tayin eder.

Madde 36 - Is ve ekonomi şartlàrın tayin ve islâhı için sendika veya patron birlikler halinde birleşme hürriyeti herkese tanınmıstır.

Hiç kimse böyle bir birliğe üye olmağa zorlanamaz veya mani olunamaz.

Madde 37 - Bütün işletme ve resmî makamlardaki müstahdem, iş̧i ve memurlar sendikaların delâletiyle müșterek işletme temșil heyetleri kurarlar. Bụlar iş alanlar tarafından umumî, eșit, hür, gizli ve vasıtasız seçim usulü ile seçilirler.

tşletme temsil heyetlerinin görevi sendikaların eşit haklar dahilinde is verenlerle iģletmenin sosyal, şahsî ve ekonomik meselelerini tespit etmektir. Teferruạti kanun tayin eder.

Madde 38 - Memleket ekonomisinin ödevi bütün milletin refahına ve ihtiyaçlarnnun tatminine hizmet etmektir. Kanun bu maksatla istihsal, imal ve dağıtımin elverişli şekilḍe tanzimini ve herkesin bütün işlerin ekonomik semeresinden pay almasını ve türlü istismardan korunmasinı sağlayacak rasyonal tedbirler alır.

Bu çerçevenin dahilinde ekonomik faaliyet serbesttir.

Sendika ve işverenlerin temsilcileri devletin idare tedbirleri tahakkuk ettirecek olan organlarda eşit söz hakkına sahiptirler.

Madde 39 - Tekelci ve siyasî iktidarın teşekküllere yöneltilen elkonomik hürriyetin her türlü kötüye kullanılışı şiddetle yasaktır.

Ekonomik hüirriyetin kötüye kullanma tehlikesini taşlyan servetler kanunu kararlara müsteniden kamulaştırılır.

Kamulaştırılması ekonomik bakımdan elverişsiz olan servetler kanunî kararlara müsteniden devlet kontrolü altına konulur veya devletçe tayin edilen organlarla idare edilir. Bu şartların mevcudiyetini kanun tayin eder.

Kamulaştrimlan servete verilen tazminat sosyal bir görlisle kanun tarafindan tespit edilir.

Ekonomik kudretin kötliye kullanlması hallerinde kaideten tazminat verilmez.

Madde 40 - Kamu malı halkın mahdır. Bu mülkiyet uzerindeki tasarruf ve idare daha etraflı kanunî kararlara müsteniden bu malın münhasıran büttin milletin refahına hizmet edeceği ve iktisad kudret terakkümüne meydan vermiyeceğine teminat gösteren hak hâmillerine tanınmalıdır. 
Madde 41 - Bu mackde hakkinda özel bir referandum yapılarak seçmenłere bunun snayasaya alınip alınmıyacağı sorulacak. Terclimenin sonuna bakınız.

Madde 42 - özel kanunlarm ölçüsüne göre tarihi tecrubbelerce siyasî sui istimslin tehlikesine veya militarist gayretlerin teșkiline meydan veren büyük arazi mullkiyeti bir toprak reformu ile kaldırilir.

Toprak reformun gayesi herşeyden önce ekim ve ormanciliğa elverişli toprağ muhafaza ve çoğaltmak, verimini arttırmak, köylüleri iskân etmek, sıhhî evler, küçük gög̨men merkezleri ve kü̧̧ük bahçeler kurmaktır. Parça mülkiyet işe yarar hale getirilmelidir.

Sahibi tarafindan nizama uygun bir idareden mahrum edilen arazi etraflı kanunt kararlara müsteniden kamulaştırilir.

Sahibine verilecek tazminat Mad. 39 f. 4 göre tayin edilir.

Madde 43 - Tarım, kủçük sanat, eliģi ve ticaret alanındaki bağımsız küçük vo orta işletmeler kanuns mevzuat ve idare yardımı ile geliştirilmeli ve bilhassa fazla ylukten ve ortadan kalkmaktan korunmalidir.

Bu maksatla kooperatif suretile yardımlaşma teşkilatı geliştirilmelidir.

Madde 44 - Kooperatifcilik teşvik edilmelidir.

Madde 45 - Ozel mükiyet mulemmendir. Muhtevası ve sinirları kanun tarafindan cizilir. Herkes kanuna müsteniden mülkiyet edinmek ve üzerinde tasarruf etmek hakkuna sahiptir.

Ozel mullkiyet topluluğa karģı mưkellef kular. tstimali topluluğun menfaatine aykan duşmemelidir. Bu mulkiyet ancak bir kanuna müsteniden ve bu kanunda yaz1h usullere uygun olarak ve takdir edilen tazminat karşllğında tahdit veya kamulagturilabilir.

Kanunlar aksine tesbit etmedikçe kamulaştırma bedellerin tarz veya miktan hakkindaki ihtilafların rüyeti adi mahkemeler tarafindan yapılir. Miras hakkı medeni kanun ölçisüune göre tanınır. Devletin vereseden alacağı pay kanunla tesbit edilir.

Madde 46 - Mucit, sanatkar ve müellif hakları devlet tarafindan korunur.

Madde 47 - Servet ve gelir bilhassa aile yüklerini nazara alınarak ve sosyal bir görlişle müterakki bir vergiye tabi tutulur. Vergi tahsilinde emekle edinilen servet ve gelire özel bir itina gösterilir.

\section{DEVLET, KILISE, DIN VE DUNYA GÖRUSLERI TOPLULUKLARI}

Madde 48 - Serbestçe ve alenen dinî âdetlerin icrası ve din ile dünya görug ortaklıkları halinde birleşme hürriyetine müsaade edilir.

Hiç kimse bir kilise hareketi veya töreni yahut dini ayine iştirak yahutda din̊ bir yemin kullanmağa zorlanamaz ve bundan men edilemez.

Devlet dini yoktur.

Madde 49 - Her kilise, din̊ veya dünya görüs topluluğu işlerini herkes için cârî olan kanun çerçevesinde bağımsız olarak idare eder. Memuriyetleri devlet veya belediyenin iştiraki olmaksızın tayin eder.

Madde 50 - Anlaşmaların ve kanunun ödevi devlet ve kilise alanların karşullkh olarak sinirlandirmaktir.

- Kulise dinî veya dinya görilg topluluklan devlęt gibl diğer tarafm iglerine $m u$ dahaleden sakinmalıdır. 


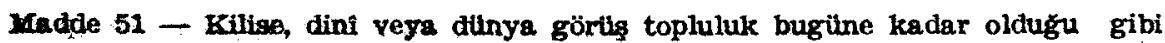
amme hukuku tesckkilii olarak kahrlar. Diğer din ve dünya görits topluluklan tịzllkderi ve lyye saylari ile devaml olduklan sabit olursa, ayni hukuki durumu iktisap edibilirier.

Kilise, din ve dünya görü̆ topluluklarụn birieșmesine bir engel yoktur. Birkaç âmme hukuku topluluklardan tegelkkul eden birlik de bir amme hukuku teşekkillidiir.

Amme hukuku teşekkülü olan kilise, din ve dünya görilşỉ topluluklan umumi vergi listeleri tanzim eden kanuni mevzuata dayanarak vergi tahsil edebilirler.

Mađde 52 - Kanun, anlaşma veya diğer bir hukukí sebeple kilise, dinî ve dünya görtłs topluluklarına devletçe yapılacak malî yardımlar kanunla kaldırılır.

Madde 53 - Pazar ve devletçe bayram olarak kabul edilen günler dinlerme ve ruhi selamet gitnleri olarak kanunen korunur.

Madde 54 - Hastane, cezaevleri ve diğer umumî mliesseselerde dini âyine ihtiyaç olduğu nisbetde kilise, dini ve dinya göriş topluluklari dinî harekete mezundurlar. Bu arada her türlil cebir memnudur.

\section{EGITHM VE OKUL.}

Madde 55 - Gençliğ topluluk dügüncesi ile bedenî, zihnî ve ruhî çalıgkanlik esaslarına göre yetistirmek ana babaların hak ve ödevidir. Bu hak onlardan ancak kanunun ölçlisilne göre hâkim kararı ile nezedilebilir.

Madde 56 - Okula devam mecburidir. Okullar bir devlet işidir. Okulların teftiģi multehassıslarca yapılır. Hessen'in blutlin okullannda bilumum dini kanaat ve dunya görüşü taşıyan çocuklar kaide olarak birlikte okutulurlar. (Topluluk okulu).

Her tỉrlü ögretimin esası mủsamaha olmalıdır. Ogretmen her derste bütün öğrencilerin din ve dünya görụ̧̈̂ü duygularn gözetmek ve đin ile dünya görülslerini objektif bir sekilde izah zorundadir.

Eg gitimin gayesi genc insanı ahlaki bir şahsiyet olarak yoğurmak, mesleki dirayet ve siyasi mesuliyetini hazırlamak, onu sayg1, hemcinsini sevmek, hakkunda sevgi, müsamaha, dịristlük ve hakikatseverlik yolu ile millet ve insanliğa kargi hizmetini ifaya hazarlamaktur.

Tarih ögretimi geçmiģin sadak, tağyir ve tahrif edilmemiş bir sekilde izahına yöneltilmelidir. Bu arada askerî sefler, harpler ve muharebeler yerine insanh̆ga büylik iyilikler sagłamıg olan devlet, ekonomi, medeniyet ve kültürün yayılmasuna amil olan kimseler üzerinde durulmalıdr. Demokratik devletin temellerini tehlikeye dựüren görüşlere yer verilmez.

Veliler 2 ilâ 5 flkralar prensiplerini ihlâl etmemek şartiyle ögretim ișinin tanziminde istirak hakkına haizdirler. Teferruatı kanun tayin eder.

Velilerin telkin etmek istedikleri din ve düya görüşü prensiplerinin ihlâl edilmemesi için okullarda gerekli tedbir alınmalıdır.

Madde 57 - Din ögrretimi proğrama dahil bir derstir. Ögretmen din ögretiminde devletin teftiş hakkını ihlâl etmemek şartiyle mensup olduğu kilise veya din cemaatını âkide ve nizamları ile bağlıdr.

Bu kararlar maksada uygun olarak dünya görüs topluluklarina da uygulanir.

Madde 58 - Cocuğun din derslerine iştịrak hususunda karar vermek veliye aittir. Hic bir blratuen din derai vermeze zorlanamaz veye verilmesino engol olunamaz. 
Madde 59 -. Bütün umumî ilk, orta, lise ve yưksek okullarda öğretim parasızdır. Yüksek okullar hariç kullanılan bütlin ders vasıtaları da parasızdır. Kanun sosyal bakımdan zayıf durumda olanların istidatlı çocuklamna tahsil yardımı yapıması için tedbir alır. öğrencinin ana baba veya nafakası ile mükellef olanın iktisadî durumu müsait olduğu takdirde münasip bir okul ủcreti vermesi kanunla emrolunabilir. Orta, lise ve yüksek okullara girişi tayin eden ölçù sadece ögrencinin iștidadidir.

Madde 60 - Üniversite ve devletin yüksek okulları devletin himayesinden faydalanirlar ve onun nezaretine tâbidirler. Bu müesseseler muhtariyetle idare olunurlar. Ögrenciler de bu muhtar idareye katılırlar.

Universitelerin ilâhiyat faktüteleri bâki kalırlar. Bunların ögretim üyelerinin tayininden önce kilisenin de mütalâası alınır.

Kiliselerin din ögretim müesseseleri tanimr.

Madde 61 - Özel orta, lise ve yuiksek okullarla pedagojik bir karakter taşyan okulların açılması devletin iznine bağhıdır. OOzel okullar ögretim gayeleri, teşkilat ve ögretim elemanları ilmi formasyonu bakımından umumî okullardan geri iseler, velilerin servet derecesine göre bir ayrılı̆̆a meydan verirlerse veya ögrretim elemanlarının ekonomik ve hukukî durumu kâfi teminat altına alınmamışsa, bunlara müsaade edilmez. Teferruatı kanun tayin eder.

Madde 62 - Sanat, tarih ve kültur ile tabiatın anitlar ve devletin ve belediyelerin himâye ye bakımından faydalanırlar. Alman sehir, kôy ve kolonilerin imarı ve kuruiuşunda devlet ve belediyeler hususî kanunlar çerçevesinde buniara güzel sanatlar bakimindan tanzimine nezaret ederler.

\section{KAMU HAKLARINA DAIR MUSTEREK HUKUMLER}

Madde 63 -... Bundan önceki kamu haklarından anayasanın kanunla tahdidine cevaz verdiği yahut teferruat itibariyle tanzimini bu kanuna havale ettiği hususlarda kamu hakkı aslında dokunulmaz olarak kalır.

Bu manada kanun yalnız halk veya meclis tarafindan umumí bağlayıcı mahiyette isdar olunan ve bir kanun hakkınin sarih sekilde tahdit ve tanzimini ihtiva eden hukkümlerdir. Nizamnameler kanun metninde diğer eski nizamata atıflar umumî kanunî salâhiyetlerin yorumlanmasından kazanılan hükümler bu şartları haiz sayılmazlar.

\section{IKINCI KISIM}

\section{MEMLEKETTN KURULUSU}

$$
\text { I Hessen }
$$

Madde 64 - Hessen Alman cumhuriyetinin bir uzvudur.

Madde 65 - Hessen demokratik ve parlamenter bir cumhuriyettir.

Madde 66 - Mills. renkler kirmızı beyazdır. 


\section{II - Devletler hukuku bağlantıları}

Madde 67 - Devletler hukuku kaideleri milli hukukta sarih bir şekil almağa hacet kalmaksızın memleket hukukunun bağlayıcı unsurları sayılırlar. Bu kaidelere veya bir devlet antlaşmasına aykın düşen hiçbir kanun muteber değildir.

Madde 68 - Devlet hukuku ödevlerini ihlâl mahiyetini taşıyan fiilleri yapmadiğından dolayı kimse sorumlu tutulamaz.

Madde 69 - Hessen barış, hürriyet ve milletlerarası anlaşma esaslarını benimsemiştir. Harp mezmumdur.

Bir harbi hazirlama gayesiyle yaplan her hareket anayasaya aykırıdır.

$$
\text { III - Hâkimiyet }
$$

Madde 70 - Hakimiyet vazgeçilmez surette milletindir.

Madde 71 - Millet hakimiyetini anayasanın hükümlerine göre doğrudan doğruya halk oyu (seçim, teklif ve referandum), dolayısiyle anayasaya uygun kurulan organların kararları delâletiyle kullanır.

Madde 72 - Oy hürriyeti ve oy gizliliği mahfuzdur.

Madde 73 - Hessen'de mesken sahibi olup seçim hakkından mahrum edilmiyen 21 yaşını bitirmiş ve Alman vatandaşı oy hakkına sahiptir. Oy hakkı umumî, eşit, gizli ve vasıtasızdır. Oy verileceği gün bir pazar veya âdi bir cuma olmalıdır.

Teferruatı kanun tayin eder.

Madde $74-1$ - Reşit olmayan veya geçici vesayet altına alınan yahutta aki malúliyeti dolayısiyle hacir altında bulunan.

2 - Vatandaşlık hakkına tam ehil olmayanlar oy hakkından mahrum edilirler.

\section{VI - Milli Moclis}

Madde 75 - Millî meclis nispi usul prensiplerine uygun olarak halktan seçilen saylavlardan terekkiup eder. 25 yașinı doldurmuş oy hakkı sahipleri meclise seçilebilirler.

Teferruat kanun tespit eder. Milli mecliste temsil edilmek isteyen bir seçim gurubu verilen yưz muteber oydan asgarî beş oyuna sahip olmalıdur.

Madde 76 - Herkese milli meclise seçilmek ve saylavlığını engelsiz ve zararsız ifa etmek imkânı sağlanmalıdır.

Teferruatı kanun tayin eder.

Madde 77 - Saylavlar bütün milletin temsilcileridir.

Madde 78 - Seçimlerin muteberliğ̣i millî meclis tarafından teşkil edilen bir seçimi inceleme muhakemesi tarafından tetkik edilir. Saylavlığın sukutu hakkında karar verme yetkisi de bu mahkemeye aittir. Seçim usulünde nizamsızlık veya seçim neticesine müessir olan cezayı müstelzim veya ahlaka mugayir hareketler seçimi gayri muteber bir hale getirir.

Seçimi inceleme mahkemesi memleketin en yủksek ikì yargıcı ile millî meclisince bir devre için seçilen ụ̈ saylavdan teşekkül eder. Teferruat kanư tarafindan tayin edilir.

Madde 79 - Milli meclis dört yll müddetle seçilir. (Seçim devresi) Yeni seçimler seçim devresinin hitama ermesinden önce yapılmalıdır. 
Madde 80 -... Millî meclis kendini üyelerinin tam sayısının yarısından fazlası ile verilen bir kararla fesheder.

Madde 81 - Milli meclisin feshini takiben yeni seçimler altmıs gün zarfında yapulmalidir.

Madde 83 - Eski meclis feshedildiği takdirde yeni meclisin seçim devresi yeni secimin yapudiğı gün, normal hallerde ise eski seçim devresinin sona erdiği gün baslar.

Madde 83 - Millî meclis kaideten millî hükûmetin bulunduğu şehirde toplanır. Milli meclis seçimin yapıldığından 18 gün sonra kendiliğinden toplanır. Eğer o gün eski meclisin seçim devresi henizz bitmemişse, yeni meclis bu seçim devresinin sona ermesini takip eden gün toplanur.

Sözù geçen günlerden biri pazar veya cumaya isabet ettiği takdirde meclis ancak o günủ takip eden ikinci çalışma günü toplanır.

Meclis oturumunun tâliki, tatili (oturum devresi) ve yeniden toplanma günü hakkunda karar verir. Milli meclisin baskan meclisi her zaman davet edebilir. Hïkumet veya üyelerinin tam saysinin beşte biri bunu talep ettiği takdirde baskan bu daveti yapmak zorundadir.

Madde 84 - Milli meclis başkan, yardumcıların ve idare heyetin diğer üyelerini secer.

Madde 85 - Iki oturum arasında ve yeni seçilen bir meclisin toplanmasina kadar başkan ve yardımeiların meclisin son oturumun işlerini devam ettirirler. Bunlar 95 - 98 ci maddelerde tesbit edilen haklardan faydalanirlar.

Madde 86 - Meclis başkan bütçe kanunun ölçüsüne göre meclisin bütün iktisadi işlerini tedvir eder. Meclisin bütün memur, müstahdem ve işçilerini idaresi ile meclis idare heyetinin muvafakatı ile meclis memurlarının tayin ve azli başkana aittir. Meclis başkanı idaresine taallak eden bütün hukukî işler ve ihtilaflarında Hes. sen'i temsil eder. Meclis binasinda tasarruf hakka ve zabita ona aittir.

Madde 87 - Millî meclis ancak üyelerin tam sayısınun yamsından fazlası hazır bulunduğu takdirde müzakere ve karar verme imkânina sahiptir. Millî meclis ta. rafindan yapılacak seçimlerde içtüzük hususî hüküimler ihtiva edebilir.

Madde 88 - Milli meclis kararlarını "Evet" veya "Hayr" şeklindeki olayların çŏ̌unluğu ile verir. Verilen oyların eşitliği yapılan teklifin ređdi manasına gelir.

Madde 89 - Meclisin oturumları âlenidir. Hükamet veya on saylavin teklifi ile meclis mevcut üyenin üçte ikisinin çoğunluğu ile gündemin münferit maddeleri için kapalı oturum yapabilir. Bu konudaki teklif gizli oturumda görüşülür.

Madde 90 - Hessen ve her hangi başka bir Alman millî meclisinin ve komisyonlammin açik oturumlarındaki müzakerelere dair verilen hakikate uygun haberler her türlü sorumluluktan âridir.

Madde 91 - Millî meclis ve komisyonlam başbakan ve dĭger bakaniarin mizakerelerde hazir bulunmasın taleb edebilirler. Başbakan, bakanlar veya onlarin tavzif ettikleri temsilciler millî meclis ve komisyonlarının oturumlarına girme hakkına haizdirler. Bunlar gündem dışında da her zaman söz alabilirler. Oturumlarda bulunanlar başkanın idaresine tâbidirler.

Madde 92 - Mills meclis soruşturma komisyonları kurmak hakkına sahiptir. for bunu uyelerin tam saysinin beste biri talep ederse, komisyonun kurulmasn bir odev halini alır. Bu komisyonlar açık oturumlarda kendileri veya teklif sahiplerinin 
Iuzumlu gördukleri delilleri toplarlar. Uç̧te iki kararla oturumlari gizli yapabilirler. Soruşturma usul, ve komisyon üyelerinin saysi içtuzukkle tayin olunur.

Mahkeme ve idari makamlar bu komisyonlarin talep ettikleri bilgi ve delilleri verme de mükelleftirler. Resmî makam ve tesekkuller komisyonlara istenen evraki vermekle mükelleftirler. Komisyonlarin delil toplamları ve bilgisine basvuracakları memurlar hakłonda ceza hukuku usulü kaideleri uygun şekilde tatbik olunur, su kadar ki posta sirrı mahfuz kalir.

Madde 93 - Milli meclis daimî bir komisyon (baskomisyon) seçer. Bu komisyon millî meclisin toplanmadı̆̆ı, bir seçim devresinin sona erdiği zamanlarda yahut milli meclisin feshi ile yenisinin toplanması arasinda milli hülkumet karşısında milleti temsil hakkına sahiptir. Bu komisyon ayni zamanda bir soruşturma komisyonun haklarına da sahiptir. Komisyonun kuruluş tarzl içtüzükle tayin olunur. Uyeler 95 - 98 ci maddelerde tesbit edilen haklardan faydalanirlar.

Madde 94 - Millî meclis kendisine tevcih edilen dilekleri hükúmete havale edebilir ve vaki teklif ve şikâyetler hakkında hükametten bilgi isteyebilir.

Madde 95 - Hessen veya başka bir Alman millî meclisinin hị̣ bir üyesi verdigi oylardan veya saylavlık faaliyeti esnasinda yaptığı beyanattan dolayı kazai veya inzibatí yoldan takip edilemediği gibi toplantı dışında herhangi bir suretle sorumlu tutulamaz.

Madde 96 - Hessen veya başka bir Alman milli meclisinin hiçbir uyesi saylavm mensup olduğu meclisin izni olmadıkça seçim devresi müddetince cezayı müstelzim bir hareketten dolayı sorguya çekilemez veya tevkif edilemez meger ki thye bu filli işlenmesi anında yahut en geç ertesi gün yakalanmış olsun.

Saylavlık faaliyetinin icrasını tahdit eden şahsî hürriyetin herhangi bir başka suretle tahdidi de ayni müsaadeye bağlıdır.

Hessen veya başka bir Alman milli meclisinin üyesine karşı yapılan her türlü cezai takibat, tevkif veya şahsi hürriyetinin başka türlü tahdidi saylavin mensub olduğu meclisin talebi túzerine seçim devresinin sonuna burakılır.

Bir gazete veya derginin mesul yazı isleri müdürü sıfatiyle cezayı müstelzim fiilden dolayı takip edilen saylav yukarda geçen hükümlerden faydalanamaz.

Madde 97 - Hessen veya başka bir Alman millî meclisinin tuyeleri kendilerine saylav olma sıfatiyle yahut saylavlık faaliyetinin icrası sebebiyle bazı hâdiselere ait surları tevdi etmiş kimseler hakkmda bizzat şahitlikte bulunmaktan imtina edebilirler. Yazllı vesikaların müsaderesi bakımından da kanunen şahitlik etmekten imtina etmek hakkına sahip olan kimselerin durumundadırlar. Hessen mivî meclis binasında ancak başkanın izniyle araştırma ve müisadere yapilabilir.

Madde 98 - Milli meclisin üyeleri Hessen'de mevcut bütün devlet ulaştırma vasitalarinda parasiz seyahat ederler. Ayrica seyahat masraflam ile hakki huzurlam verilir. Bundan başkan, başkan makammı işgal ettiği müddetçe bir tazminat alır:

Bu haklardan feragat caiz değildir.

Teferruatı kanun tayin eder.

Madde 99 - Milli meclis içtüzüğüini anayasa çerçevesinde tesbit eder.

\section{V - Hükûmet}

Madde 100 - Hükumet (kabine) başkan ve bakanlarden terekktị eder.

Madde 101 - Meclis ityelerinin tam sayısının yarısindan fazlasiyle mijakkerasiz begbakany secer. 
Teferruatı içtüzük tayin eder.

Başbakan bakanları tayin eder ve tayinlerini geciktirmeden meclise bildirir.

1918 e kadar Almanya'da veya başka bir memlekette saltanat sürmüş ve sürmekte bulunan hanedan mensuplar hükúmet ủyesi olamazlar.

Hükumet ancak meclisin özel bir kararla verdiği itimat oyundan sonra işe başlayabilirler.

Madde 102 - Başbakan hükamet politikasının anahatlarını tayin eder ve bundan dolayı meclise karşı sorumludur. Bu anahatlar dahilinde her bakan kendine ayrian iş sahasını müstakilen ve meclise karşı şahsen sorumlu olarak yürütür.

Madde 103 - Başbakan Hessen'i temsil eder. Temsil yetkisini selâhiyetli bakanlara yahut onlara tabi olan makamlara devredebilir. Devlet sözleşmeleri meclisin muvafakatine bağhdır.

Madde 104 - Başbakan hükûmete başkanlık eder ve işlerini yürütür. Bu oyların eşitliğinde başbakanın bulunduğu taraf tercih olunur. Diğer teferruatı hükúmet bir tüzükle tesbit eder. Kanunî açı hükümler bulunmadiğı takdirde hükamet her bakanın yetkisini kararlaştırır. Bu kararlar geciktirilmeden meclise sunulur ve meclisin talebi ile değiștirilir veya yürürlükten kaldırılır.

Birkaç bakanın icraatına taalluk eden meselelerde çıkan görüş̧ ayrılıklan müzakere ile karar vermek üzere hükamete sunulur.

Madde 105 - Hükûmet üyeleri maaş almağa hak sahibidirler. Emekli maaşi ve geri kalanların infakı için hususi hukümler konur.

Madde 106 - Meclise sevkedilecek kanun tasarıları hakkında hükûmet karar verir.

Madde 107 -.- Bir kanunun tatbiki için gerekli hukuk ve idare nizamnemelerini -eğer bu vazife kanunla münferit bakanlıklara verilmemiş ise- hükûmet isdar eder.

Madde 108 -- Kanunda başka hüküm bulunmadıça devlet memurlarının tayini hükûmete aittir. Bu yetki başka makamlara devredilebilir.

Madde 109 -- Başbakan millet namina af salâhiyetini kullanmaktadır. Bu yetkiyi başka makamlara devredebilir. Bir idam cezasının tasdiki hükumete racidir.

Vazifesinin ifası dolayısiyle mahkûm edilen bir bakan hakkındaki af hakkı ancak meclisin talebi üzerine kullanilabilir.

Umumî af ve muayyen bir nevi kazấ cezaların ilgası meclisin tasvibine bağhıdır. Münferit bir kazai cezanın ilgasina cevaz yoktur.

Madde 110 - Tabî âfet veya dı̧ tesirlerden dolayı vuku bulan bir olağanüstü mecburiyet halinin âcilen bertaraf edilmesi gerektiği takdirde eğer meclis toplantı halinde değilse yahutta vaktinde toplanamazsa, hükûmet 93 cü maddede derpiş edilen daimi komisyonun muvafakatı ve anayasaya aykırı olmamak sartiyle kanun kuvvetinde nizamnameler isdar edebilir. Bu nizamnameler meclisin ilk toplantisinda tas. vibine arz olunmalıdır. Tasvib edilmediği takdirde nizamname resmî gazete yolu ile yürürlükten kaldırılir. Madde 122 de buna uygun olarak caridir.

Madde 11 - Vazifesine başlarken başbakan meclis huzurunda, bakanlar ise mecliste başbakan huzurunda aşağıdaki yemini ederler :

"Bana verilen vazifeyi bitaraf bir șekilde bütün bilgi ve iktidarımı kullanarak yürütmeğe ve anayasa ile kanunları demokratik bir zihniyetle takip ve müdafa edeceğime yemin ederim."

Madde 112 -... Başbakan her bakanı meclisin muvafakatiyle vazifesinden af eđebilir. 
Madde 113 - Başbakan ve bakanlar her zaman çekilebilirler. Başbakanin istifa veya ölümü ayni zamanda hükametin istifasi manasına gelir.

Başbakan ve luülkamet yeni seçilen meclisin ilk toplantısında çekilmek zorúndadır.

Htikamet çekildiği veya meclis kendisine itimat etmediği hallerde işleri yeni hiultumete devredinceye kadar yürutmege devam eder.

Madde 114 - Meclis açık bir kararla yahut güven oyu teklifinin reddi suretiyle başbakanı güveninden mahrum edebilir. Başbakana güven veya güvensizlik teklifi saylavların tam sayısınin en aşag altıda biri tarafından yapılmalıdır. Güven meselesi hakkında bir kararin alınmasi en erken görüşmelerin bitmesinden iki gün sonra ve en gec teklifin yapılmasından on gün sonra oya sunulmalıdir.

Gliven açlk oyla (ismen) belirtilir. Mesela başbakan için guvensizlik kararı vermesi halinde, bu karara üye tam sayısinı yarısindan fazlasınin katılması șarttır.

Böyle bir karar karşısında başbalkan çekilmeğe mecburdur.

Meclis oniki glun içinde yeni bir hükamete gưvenini bildirmediği takdirde feshe. dilmiş sayılır.

Madde 115 - Meclis hükûmetin her üyesini anayasa veya kanunları kusurlu olarak ihlâl etmesinden dolayı yüksek devlet mahkemesinde dava edebilir. Dava aȩılması teklifi en aşağı 15 meclis üyesi tarafından imza olunmalı ve tiyelerinin tam sayısınin üçte ikisi tarafından kabul olunmak gerektir.

Meclisin dava hakkı sanığın ister ithamdan evvel veya sonra olsun vazifesinden çekilmesi ve çektirilmesiyle düşmez.

Teferruati kanun tayin eder.

\section{VI - Yasama görevi}

Madde 116 - Yasama görevi :

a) Referandum șeklinde halk tarafindan.

b) Meclis tarafindan yapllir.

Referandum halleri dışında meclis bu anayasa çerçevesinde kanunlari yapar ve bunların tatbikini nezaret eder. lanir.

Madde 117 - Kanun tasarıları hükûmet, meclis veya halkın isteği üzerine hazır-

Madde 118 - Yasama görevinin bütünü veya bir kısmına taallak etmemek şartiyle hukamete belli, münferit konular tzerinde nizamnameler çıartmak hakkı kamunen taninabilir.

Madde 119 - Meclis tarafindan kararlaştırılan bir kanuna karşı hükamet itiraz edebilir.

ttiraz beş gün içinde, gerekçesi de nihai kararı takip eđen iki hafta içinde meclise bildirilmelidir. Itiraz meclisin yeniden mïzakereye başlamasına kadar geri almabilir.

Meclis ile hükamet arasında bir mutabakat hasıl olmadığı takdirde kanun ancak meclis ilyelerinin tam sayısının yarısından fazlası itirazın aleyhine oy verdigi takdirde yurülüge girer.

:. Madde 120 - Basbakan ve bakanlar anayasaya uygun olarak vủcud bulan kanunları hazırlamak ve onları iki hafta içinde resmî gazetede ilân etmekle mulkelleftir.

Madde:121 - Kanunlar aksi kararlaștırimadıkça resmi gazetede yayninindıktan ondört gün sonra yürürlüğe girerler. 
Madde 122 - Resmî gazete vaktinde ģkmadı̆̆ı takdirde kanun baska vasıtalarla jân edilir. Bu takdirde resmî gazetede ilan edilme keyfiyeti imkân olur olmar telaft edilmelidir.

Madde 123 -.. Anayasanın hükümleri anayasa metnini değiştirmek veya ek bir hủkủm ilâve etmek suretiyle yasama görevinin çerçevesinde tâdil edilebilir. Anayasa tâdili meclis üyelerinin tam sayısını yarısından fazlasının karar ve seçmenlerin coğunluğunun oy vermesiyle gerçekleşir.

Madde 124 - Ehil seçmenlerin beşte biri bir kanun tasarısınm sumulmasın istedikleri takdirde referandum yapilır. Referandum etraflıca hazırlanmış bir kanun tasarısına istinaden yapılmałıdır. Bütçe, vergi kanunu veya ücret nizamnamesini bir halkın kanun teklifi konusu olamaz.

Halk tarafindan teklif olunan kanun hükâmetçe görüşünün izahı ile birlikte meclise sunulur. Meclis istenen kanun tasarısını değiştirmeden kabul ettiğ takdirde referanduma lüzum kalmaz.

Referandumda oy verme ancak evet veya hayır şeklinde olur. Karar verilen oyların çoğunluğu ile tayin olunur. Halkın kanun teklifinde ve referandumda takip edilecek usul kanunla tayin edilir.

Madde 125 - Memleketin anayasa durumunun tehlikeye düşüp düşmediğini ancak meclis tesbit edebilir. Bunun için üye tam sayısının en aşağı üçte ikisinin muvafakatı lázımdır. Bu karar meclis başkanı tarafından ilân edilir. Sözù geçen kararla seyahat serbestisini, posta sirrın, toplanma hakkın, ve basın hürriyetini yuruürlukten kaldırmak veya tahđit etmek mümkündür.

Daha kısa bir müddet tayin edilmediği takdirde bu karar üç ay sonra tesirini kaybeder. Karar ayni şartlar altında yenilebilir.

\section{VII - Kaza kuvveti}

Madde 126 - Kaza kuvveti münhasıran kanunlar tarafından tayin edilen mahkemelerce ifa edilir.

Yargıçlar bağımsız ve yalnız kanuna tabidir.

Madde 127 - Daimî kaza yetkisine sahip esas yargıçlar kaydı hayat şartı ile tayin olunurlar.

Geçici bir vazifede kanunda yazllı muayyen bir tecrübe devresinden sonra sahsiyet ve kazaî faallyeti, vazifesinin demokrasî zihniyeti ve sosyal anlayış çerçevesi içerisinde ifa edeceğine kesin teminat teşkil eden kimseler ancak kaydı hayat şartiyle hakim tayin olunabilirler.

Tecrübe devresi kaydı hayat şartiyle tayin meselesinde adalet bakanı yargıçları seçme komisyonu ile birlikte karar verir.

Kaydi hayat şartiyle tayin olunan bir hâkim kendisinden beklenileni yerine getirmedigi takdirde yuksek devlet mahkemesi meclisin talebi üzerine onu memuriyetten şlkartmak ve ayni zamanda başka bir memuriyete tayin etmek veya emekliye ayırmak yahut da azletmesi hususlarında karar verebilir. Talep yargıçarı seçme komisyonunun muvafakatiyle adalet bakani tarafindan da yapilabilir. Bu muamele sirasinda yargicin mesleki faaliyeti durur.

Tefermatı kanun tayin eder, bu kanum bu giine kadsp tayin olunmus hakimler hakkinda da tatbik oluriur. 
1 - 4 fikraları jüri yargıcları için caiz değildir.

Madde 128 - Yukarda yazil haller haric kaydi hayat sartiyle tayin olunan yargı̧ ancak kanun tarafından tesbit edilen şekiller altında ve kazal bir hükümle ma. kamından uzaklaştırılabilir. Başka bir vazifeye nakledilir veya emekliye ayrilur. Yasama kuvveti yargıcın emekliye ayrılmasın gerektiren bir yas haddi tesbit edebilir .

Kanun hükmüne uygun olarak geçici surette vazifeden kaldırma hususu bu esaslara tatbik olunmaz.

Mahkeme teşkilatında veya bölgesinde yapılan değişikliklerde hükâmet bir yargicm dileğine aykım olarak ancak tam maaşla başka bir mahkemeye verebilir veya vazifeden uzaklaştırabilir.

Madde 129 - Kimse imkânlarının kifayetsizliği sebebiyle kanını hakkını takip etmekten men edilemez.

Teferruatı kanun tayin eder.

\section{VII - Yüksek devlet mahkemesi}

Madde 130 - Yüksek devlet mahkemesi beş yargıçla meclise dahil olmayan ve nisbi usule göre seçilen altı üyeden ibaret olmak uzere onbir üyeden kurulur. Ayrnca bir de begsavei bulunur.

Yargiçlar muayyen müddetle diğer üyeler ise bir seçim devresinden öbtir seçim devresine kadar meclis tarafından seçilirler. Tekrar seçilme caizdir.

Yuksek devlet mahkemesi tesekkiulune ait teferruat ile tatbik edilecek usul ve kararlarmin infazma taallak eden hususlar kanunla tespit edilir.

Madde 131 - Yüksek devlet mahkemesi kanunlarının anayasaya uygunluğu, oy verme neticelerine vaki itirazla da anahakların ihlâli, anayasa ihtilâfları ve anayasa ile digker kanunlarda zikredilen hususlar hakkında karar verir.

Seçmenlerin ylizde birini temsil eden bir seçmen grubu, meclis, meclis üye tam sayısınin yilzde onu, hükamet ve başbakan bu hususlarda karar verilmesini taleb edebilirler.

Herkesin hangi hal ve şartlar altinda yuksek devlet mahkemesine müracaat edeblecesini kanun tayin eder.

Madde 132 - Bir kanun veya nizamnamenin anayasaya uygun olup olmadiğ hakjanda yalniz yulksek devlet mahkemesi karar verebilir.

Mradde 133 - Bir mahkeme karar için muktazi olan bir kanun veya nizamnamey anayasaya aykırılığı neticesine varırsa bu düşüncesini kendisinin tábi bulundugu en ustin mahkeme başanina bildirir. Başkan yüksek devlet mahkemesinin kavar vermesini sağlar. Yüksek devlet mahkemesinin karari katidir ve kanun mesabesindedir.

Teferruatı kanun tayin eder.

\section{Devlet ve muhtar idare}

Madde 134 - Menşe, Irk, diní inang ve cins farkı gözetmeksizin gerelikli vasıf ve kabiliyete sahip olan herkes umumî memuriyetlere girebilir.

Madde 135 - Umumi idarede is görenlerin hukuki milnasebetleri madde 29 da derpis edlen muttehit ts Kanuninun çerçevesinde idarenin icaplamna göre tanzim olumur. 
Madde 136 -... Kendisine tevdi edilen âmme kudretinin istimalinde üçüncü bir §̧ahsa karşı memuriyet vazifesini kötüye kullananların sorumluluğu hizmetinde bulunduğu devlet veya korporasyona düşer. Memura rücu hakkı mahfuzdur. Kazaî yol daima açktır.

Tefermatı kanun tâyin eder.

Madde 137 - Belediyeler kendi bölgelerinde bïtün mahallî kamu idaresinin kendi mesuliyetleri altında biricik sahibidirler. Sarih kanunî hükümle kamu menfaati mülâhazasina binaen başka makamlara tevdi edilmiyen bütün âmme hizmetlerini deruhde edebilirler.

Beledî teşekküller kanuní yetkileri çerçevesinde ayni mevkie sahiptirler.

Belediyelerin ve beledî teşekküllerin kendi işlerinde muhtar idare hakkı devletçe temin olunur. Devletin nezareti bunların idaresinin kanunlarla mutabik bulunması hususuna inhisar eder. Belediyeler ve beledi teşekküllere yahut onların idare meclislerine kanun veya nizamname ile talimat dairesinde devlet hizmetlerinin ifasi devrolunabilir. Devlet belediye ve beledî teșekküllere gerek kendi ve gerek devrolunan hizmetlerin ifası için gerekli para vasıtasına vergi ve mall muvazene yolu ile temin eder. Bundan bașka devlet bu teşekküllerin ihtiyarî âmme faaliyeti için krendi mesuliyetleri altında idare edeceği gelir kaynakları tahsis eder.

Millî meclis seçim hakkına ait prensipler belediye ve beledî teşekküller seçimlerinde de câridirler.

Madde 138 - Belediyelerle beledi teşekküllerin baş görevlerini yapan idarecileri seçilen temsilcilerin yazılı ve gizli oyu ile seçilir.

Seçim müddetinin süresi kanunla tanzim olunur.

\section{Malî işler}

Madde 139 - Meclis lüzumlu gelir vasitalarınin tasvibi yolu ile devlet intiyacının kapatılmasını sağlar.

Devletin bütün gelir ve giderleri her bütçe yılı için hesaplanır ve bütçeye dahi! edilir. Bütçe kesin hesap yılın başlamasindan önce bir kanunla tesbit edilir.

Giderlerin sarfina kaideten bir yll için, bazı hususi hallerde de daha uzun bir sure için müsaade olunur. Bundan gayri bütçe kanununda kesin hesap yılını yahut devlet ve idarenin gelir ve giderlerine taallak etmeyen hükümlerin yer alması caiz değildir.

Madde 140 - Kesin hesap, ylln sonuna kadar gelecek yllın butçe kanunu çımadığı takdirde, hükûmet:

1 - a) Kanunen meveut müesseselerin idamesi ve kanunen almacak tedbirlerin ifasi,

b) Devletin hukukî taahhütlerinin yerine getirilmesi,

c) Daha önceki bütçe kanununda tahsisat kalđiğı takdirde inşaat, mübayaa. v.s. maksatlar için lüzumlu masrafları yapmağa yetkilidir.

2 - Özel kanunlara dayanan vergi ve gelirler birinci fikradaki masrafları kargllamağa yetmedigi takdirde hükamet üç ay için geçmiş bütçe kanununun niha meblağının dörtte bir nispetinde hazineden tahsisat ayırtabilir.

Madde 141 - tstikraz yoluna ancak olağanüstü ihtiyaçlar ve kaideten yalnız yapıc maksatlar için başurulabilir. Devlet hesabına böyle bir istikraz yapılması veya teminat gösterilmesi ancak kanun sekli ile yaplabilir. 
Madde 142 - Masraf intiva eden veyahut gelecekte masrafi davet edecek otan meclis kararları bu giderlerin hangi yoldan karşlanacağını da göstermelidir.

Madde 143 - Bütçe ve piân dişi masraflar Maliye Bakanınin muvafakatine bağhdur. Bülar ancak önceden tahmin edilemeyen ve önüne geçilemeyen hallerde caizdir.

Bütçe aşımı ve plân dı̧̧ masraflar müteakip kesin hesiap ylı içinde meclis tarafindan tasdike muhtaçtır.

Madde 144 - Butçe hesapları Sayıstay tarafından tesbit ve teftiş edilir. Her yılın bütçe hesapları ve devlet borçları hakkındaki rapor Sayıstayın mütalâa ve huikumetin noktai nazarı ile birlikte ibra için meclise sunulur.

Madde 145 - Devletin kâr getiren ekonomi teşekküllerin malî işleri 139 - 144 ünciu maddelerinden aym bir kanunla tanzim edilebilirler.

\section{Anayasanin korunması}

Madde 146 - Anayasanın varlık ve devamin elindeki bütün kuvvet ve vasitalarla sağlamak herkesin vazifesidir.

Bu ödeve aykurı hareket eden veya demokrasinin temel fikirlerine kargi mücadele eđen siyasî bir gruba dahil olan veya olmuş bulunan bir kimsenin yüksek devlet mahkemesinin kararı ile Anayasanın hangi haklardan mahrum edilebileceğini kanun tâyin eder.

Madde 147 - Anayasaya aykiri alenen kullanllan cebire kar\$1 mukavemet herkesin hak ve vazifesidir.

Anayasayı ihlâl veya böyle bir hareketi teşebblis hakkunda bilgi edinen kimse yüksek devlet mahkemesine müracaat suretiyle suçlunun cezai takibe tabi tutulmasin istemekle mukelleftir.

Teferruatı kanun tayin eder.

Madde 148 - Anayasa intilalci hareketlerden dolayı fiili tesiri ve yürïrlüüünü kısa veya uzun bir müddet için kaybettiŏi hallerde Anayasaya aykırı durum zail olur olmaż Anayasanın devrilmesinden yahut ihlalinden suçlu olanlar sorguya çekiliriler.

Madde 149 - 147 ve 148 inci maddelerinden dogan ceza hukuku neticelerini kanun tâyin eder.

Madde 150 - Anayasanın demokratik ana prensipleri ve cumhuriyetçi parlamanter devlet şekli Anayasa tâdili yoluyla değiştirilemez. .Hangi şekilde olursa olsun bir diktatörlüğự kumulmasi yasaktır.

Bu esasa aykim kanun tasamlan oya sunulmaz, ayni maksatla kararlaştimlan kanunlar isdar edilmez. Buna rağmen ilân edilen kanunlara riayet caiz değtldir.

Bu madde bir Anayasa tâdili konusu olamaz.

\section{intikal Hükümleri}

Madde 151 - Hessen Alman Cumhuriyetinin yetki iddia edebileceği sahalarda alacağ bütùn tedbirleri tekmil Almanya'nin birliğini muhafaza prensibine tâbi tutar.

Her şeyden önce mevcut hukukí birliğe mücbir bir sebep olmadikça dokunamaz. Mücbir bir sebebin mevcudiyetini kanun tayin eder.

Madde 152 - Alman Cumhurtyetinin kanun vazeden bir organ teşekkul edinceye kadar hukamet diğer Alman hükametleriyle birlikte nihai Alman birligine bir 
engel tegkil etmemek uzere hukukun bazı muayyen kssımları için müttehit bir yan sama organı vïcude getirilmesini kararlasturabilir.

Bu türlü anlaşmalar meclisin muvafakatine bağlıdır. Anlaşmalar ygsama kuvvetinin doğrudan doğruya veya dolayssiyle demokrațik seçimlerden vücude gelmiş bir organa devrini derpiş etmelidir. Bu nevi organların kararlaştırdıkları kanunlar anayasaya aykırı olmamak şartiyle Hessen'ı bağlarlar.

Madde 153 - Alman Cumhuriyeti ile Hessen arasındaki salâhiyetler blitìn Alman milletinin seçeceği bir Millı Meclis tarafından anayasaya uygun sekilde stnurlandirılur.

Alman Cumhuriyetinin müstakbel hukuku Hessen hukukundan daha önce gelir.

Madde $154 \ldots$ Kanuni hükümlere göre buttin Alman memleketlerin mensuplan yerli sayılurlar. $\mathrm{Bu}$ memleketlerin bütuin ülkesi anayurd saynlir.

Madde 155 - 123 üncü maddenin ikinci fikrasina uygun bir anayasa kanuna ile yasama görevine demokratik seçimlerden doğan bir organı daha dahil etmek hakks mahfuzdur.

Madde 156 - 56 unci maddenin yedinci frkrasinda derpiş edilen kanunun ilânna kadar okul sistemi halihazırdaki durumda kalır.

Okul bölgesindeki velilerin çoğunluğunun arzusu ile 30 Ocak 1933 de cari olan ve sonra değiștirilen münasebetleri yeniden ihdas etmek hakkı mahfuzdur. 1.1.1950 tarihine karar hali hazsrdaki durum kanunla dahi değiştirilemez. ogretim seyrinde yeni değişiklikler yapılabilmesi imkân bunun dı̧ıında kalır.

Madde 157 -- Halen mevcut zaruret hali sebebiyle isdar olunan veya ssdar olunacak kanunlarla aşağıdaki anahatlara caiz olmayan müdahalelere cevaz verilebilir.

a) Madde 6 daki seyahat serbestisi anahakka,

b) Mecburi mesken tahsisi çerçevesi içerisinde 8 nci maddedeki mesken dokunulmazilik hakkı,

c) Madde 28 deki ikinci flkrada zikredilen iș kuvvetinin serbest kullanılması hakkı ve mecburî is mükellefiyetleri kanunlan çerçevesi içerisinde ikinci madde ile ilgili hakklar.

d) Günlük ihtiyaç maddelerin kifayetsizliğini hafifletme kanunlarn ile mullkiyet uzerinde tasarruf hakk.

Anahaklarn tahdidine cevaz veren birinci fikra 31.12.1950 tarihinde yürïrlükten kalkar. Meclis tiye tam sayısının yarısından fazlası ile bu müddeti uzatabilir.

Madde 158 - Nasyonal sosyalizim ve militarizmi yenmek ve bunlarm sebep olduklan haksızlığı tamir etmek için çıkarılmıs olan veya 1.1.1949 a kadar çıarılacak olan kanunlara karşı anayasada tesbit edilen hürriyet ve haklar dermeyan edilemez.

Madde 159 - Almanyadaki kontrol komitesi ve askeri hükamet tarafindan $25-$ dar olunan emirnameler için devletler ve harp hukukuna istinaden bu anayasaya ve anayasaya uyun olarak çkarlan kanunlara ve diğer Alman hukukuna üstunlïk iddiast mahfuz kalir.

Mdde 160 - Bu anayasa millet tarafundan kabul edilmekle yïürlüğe girer. 22 kasim 1945 tarihli devlet temel kanunu ayni zamanda yïrirlükten kalkar.

$\mathrm{Bu}$ tarihte devlet işlerini yürüten hukamet yeni hukkametin kurulmasina kadar 113 üncủ maddenin üçüncì fikrasında derpiş edilen hükúmet olarak geçer. Constituant meclisin baskomisyonu ise 93 ca maddeye uygun olarak daimi komisyon mesabesindedir. 
ISk: Anayasaya oy vermek munsebetiyle 11 ci madde haklanda ayrica oy istenilecek. Secmenlere 41. maddenin anayasaya girmeai hakkinda fikirleri sorulacak. Maude 41.

Anayasanin yilutirluge girmesiyle:

1. Maden ocakları (Kömlir, demir, selik, kali = gübre), demir, celik istihsalatı enerji igletmeleri, ray ve hava hatlarna baglı ulagturma sistemi kamu mal haline getirilecektir.

2. Büyulk banka ve sigorta müesseseleri ve birinci fukrada sörü geçen, fakat merkezi Hessen'de olmayan igletmeler devlet nezareti altina konulur veya devlet eliyle iģletilir.

Teferruatı kanun tayin eder.

Kamu haline getirilecek olan igletmelerin sahibi veya idaresi ile -mukellef olan kimse tatbik kanunlann isclarna kadar bu mulesseseleri Hessen'in yeddi emini snfatiyle işletme fe devam eder.

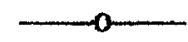

